\title{
PENGAMBILAN KEPUTUSAN DALAM PENCEGAHAN SEKS BEBAS DIKALANGAN REMAJA
}

\author{
Aruni Muharani / arunikisaran@gmail.com
}

Latar Belakang: Seks bebas adalah hubungan intim yang dilakukan secara leluasa tanpa adanya ikatan suami istri. Banyak faktor yg mempengaruhi seseorang untuk melakukan seks bebas mulai dari faktor keluarga atau lingkungan dan pergaulan. Perilaku seks bebas bisa mengakibatkan metal anak menurun jika dilakukan secara paksa atau yg paling melonjak adalah hamil diluar nikah. Para remaja sering kali terlibat dalam berbagai risiko perilaku seksual yang sangat dapat merugikan kesehatan,social,dan konsekuensi ekonomi. Oleh karena itu orang tua yang notabenenya sebagai pendidik pertama dan palingutama bagi anak dan memiliki peran yang sangat penting dalam memberikan pendidikan karakter anak agar anak tersebut dapat terhindar dan menghindari perilaku seks bebas atau seks pranikah.

Perubahan yang terjadi pada remaja baik fisik maupun psikologisnya berhubungan dengan produksi hormon seksual dalam tubuh yang dapat mengakibatkan timbulnya dorongan emosi dan seksual. Perilaku seksual dapat terjadi karena pola asuh orang tua atau lingkungan sekitar yang bisa saja menjadi salah satu dampak terjadinya seks bebas. Seks bebas dapat menyebabkan dampak yang sangat negatif seperti kehamilan yang tidak diinginkan, kerusakan mental dan penyakit menular seksual seperti HIV/AIDS. Tingginya angka mengenai seks bebas, hamil diluar nikah, dan aborsi bukti rusaknya tata pergaulan yang merusak nilai-nilai moral dan pendidikan. Budaya sekuler liberal mendorong munculnya berbagai rangsangan seksual melalui berbagai media, yang dengan mudah dapat diakses oleh para anak dibawah umur. Seks bebas masih dianggap sebagai aktivitas yang tidak sesuai dengan norma yang seharusnya, sehingga mereka sering beranggapan bahwa aktivitas berisiko ini lebih disebabkan minimnya perhatian dan kasih sayang orang tua membuat yang anak lebih mudah mencari kesenangan diluar rumah mengikuti pergaulan yang sesat.

Di zaman yang semakin berkembang ini semakin beragam pola tingkah laku serta masalah sosial yang sering terjadi di masyarakat terutama masalah pada remaja. Perkembangan teknologi saat ini sudah terlalu luas sehingga banyak memberi dampak yang sangat buruk kepada remaja sehingga menyebabkan kenakalan pada remaja. masa remaja sendiri merupakan masa dimana individu mengalami perubahan dari tahap satu ke tahap berikutnya, dan juga mengalami perubahan baik baik dari perubahan emosi, tubuh, pola pikir dan juga tinggah laku nya. 
Metode: yang digunakan dalam kajian ini adalah metode Literature review dengan menganalisis dan mengeksplorasi dari referensi yang berbeda,juga dilengkapi dengan ejournal yang mendukung dengan judul kajian ini.

Hasil: Seks bebas masih banyak dilakukan dan akan semakin meningkat angka hamil pranikah. Hal itu disebabkan oleh kurang perhatian dan kasih sayang orang tua serta faktor yang sangat memicu adalah lingkungan dan pergaulan. Dari ini kita dapat mempelajari bahwa perilaku seks bebas seharusnya dihindari mengingat banyaknya dampak negatif yang akan terjadi kedepannya,misalnya seperti hamil pada remaja perempuan, dan juga dapat mengganggu psikologis mereka. Di samping itu, perilaku seks bebas juga sangat tidak diperbolehkan untuk dilakukan secara bebas tanpa ada ikatan suami istri sesuai norma yang berlaku, dan budaya menjadi hal yang harus diingat oleh remaja karena hal ini lah yang membentuk karakter kita sebagai orang timur tanpa mengikuti karakter kebarat baratan yang tidak menentang seks bebas.

\section{PEMBAHASAN}

Rasa keingin tahu an yang sangat besar terhadap masalah seksual pada remaja sangat penting dalam pembentukan hubungan baru yang lebih matang dengan lawan jenisnya guna untuk menghindari kejadian yang tidak diinginkan. Pada masa remaja, informasi tentang masalah seksual sudah sangat seharusnya mulai diberikan agar remaja tersebut tidak mendapatkan informasi yang salah dari sumber sumber yang tidak jelas. Pemberitahuan informasi masalah seksual menjadi sangat penting terlebih lagi mengingat bahwa remaja berada dalam potensi seksual yang aktif, karena sangat berkaitan dengan dorongan seksual yang dipengaruhi hormon dan tidak cukupnya informasi mengenai aktifitas seksual mereka sendiri. Tentu saja hal tersebut akan sangat berbahaya bagi perkembangan mental dan jiwa remaja bila tidak didukung dengan pengetahuan dan informasi yang benar benar tepat (Glevinno, 2008) dalam Anna, 2010

Faktor penyebab terjadinya seks bebas di kalangan remaja sangat bermacam macam. Pengendalian diri atau membatasi diri adalah salah satu komponen yang akan sangat menentukan dilakukan atau tidak dilakukan perilaku seksual yang sangat berisiko tersebut. Remaja sering kali menganggap perilaku seksual adalah sesuatu yang wajar bila dilakukan karena atas dasar suka sama suka, selama tidak ada pemaksaan dan tidak ada yang merasa dirugikan. Meskipun mereka mengetahui bahwa hal itu sangat bertentangan dengan ajaran agama yang mereka anut, namun mereka menganggap hal itu wajar karena sudah banyak orang yang melakukannya.

Faktor penyebab selanjutnya adalah kualitas keluarga. Kualitas keluarga menjadi salah satu faktor yang dapat menyebabkan terjadinya perilaku seks bebas di kalangan remaja. Keluarga adalah unit terkecil yang di dalamnya terdapat ibu, bapak, dan anak anaknya. Anak akan bersosialisasi lewat apa yang ia lihat dengan mata kepalanya, mendengar pembicaraan orang tuanya, dan apa yang dapat ia rasakan di dalam keluarga tersebut. Ketika orang tua tidak menjalankan tugasnya dengan baik maka indikasi terjadinya penyimpangan dalam suatu keluarga akan dapat terjadi. Orang tua yang kurang memperhatikan perilaku anak-anaknya dan kurang memahami karakter anaknya dapat menjadi penyebab terjadinya seks bebas, sehingga kegagalan fungsi Orang tua dapat menjadi salah satu faktor penyebab perilaku seks pranikah. Peran orang tua 
dalam memberikan informasi dalam mengenai seks bebas sangatlah penting, tetapi ada sebagian yang orang tuanya yang memberikan informasi seputar seks bebas dan orang tua juga turut andil dalam memberikan informasi seputar seks bebas, namun ada pula orang tua yang hanya memberikan informasi seputar seks tanpa ikut andil dan berperan, orang tua hanya memberi tahu bahaya seks bebas saja, tanpa turut andil agar anaknya tidak melakukan itu. Karena tanggung jawab orang tua tidak hanya mencakup atau terbatas pada kebutuhan materi saja tetapi mencakup seluruh aspek kehidupan anak, termasuk aspek pendidikan seksual karena pendidikan seksual merupakan salah satu pendidikan karakter pada remaja untukpencegahan seksual pranikah. yang diperoleh dari keluarga khususnya orang tua lebih penting karena keluarga merupakan kunci utama dalam menegakkan sikap dan perilaku remaja dalam bermasyarakat. Tujuanpendidikan seksual adalah mendorong keterampilanatau kecakapan, sikap, kecenderungan, perlaku danrefleksi kritis terhadap pengalaman pribadi.

Orang yang minim kualitas pengetahuan terkait dampak dari perilaku seks bebas yaitu terjangkit virus HIV dan AIDS, kehamilan yang tidak diinginkan, aborsi, hamil diluar nikah, kematian karena aborsi, memalukan orang tua, berdosa,kecanduan, dan dikucilkan oleh masyarakat dan setelah informan mengetahui apa saja akibatnya dan respon orang tersebut setelah mengetahui akibatnya yaitu biasa saja, semakin menjauhi seks bebas, takut, menghindar, terkejut, dan berupaya mengkampanyekan kepada orang lain agar tidak melakukan hubungan seks diluar nikah.

HIV/AIDS adalah penyakit yang bisa saja mereka alami jika sering melakukan hubungan seksual dengan bebas. Sebagai orang tua harus mengingatkan atau menegur anak jika sudah mengikuti pergaulan yang salah karena anak sangat mudah terpengaruh oleh informasi-informasi yang belum tentu kebenarannya maka dari itu orang tua harus lebih dulu memberitahukan mengenai seksual bebas dan apa saja dampak dari tindakan mereka tersebut.

Kualitas lingkungan juga dapat mempengaruhi seks bebas dan kualitas lingkungan yang dimaksudkan itu seperti lingkungan yang kurang sehat, seperti lingkungan masyarakat yang mengalami kesenjangan komunikasi antar tetangga. Yang menjadi penyebab orang tersebut tidak pernah mendapatkan informasi tentang seks dari orang tuanya karena Sebagaian besar di dalam keluarga orang tersebut membicarakan masalah seks di anggap hal yang tidak wajar karena pandangan mereka setiap mendengar kata seks itu adalah dua orang yang sedang berhubungan intim, maka dari itu orang tua juga enggan memberitahu informasi tentang seks bebas, namun adapula di sebagian keluarga orang tersebut memberi informasi tentang seks bebas merupakan hal yang wajar dan lumrah, karna membicarakan masalah seks bebas merupakan termasuk memberi pendidikan kepada anak tersebut.

Penyebab rusaknya moral remaja dalam hal seksualitas adalah perkembangan dan kematangan seksual yang sering tidak diiringi dengan peningkatan pengetahuan agama sehingga kaum remaja dapat terlibat dalam pergaulan seks pranikah dan penyimpangan orientasi seksual. Oleh karena itu, perlu adanya penanaman dan peningkatan pengetahuan perilaku seks dan pendidikan agama sejak dini yang dapat menjadi pengontrol kaum remaja. Agama merupakan salah satu sumber nilai moral atau norma perilaku yang penting bagi jiwa remaja. Tidak adanya moral agama sering kali memicu terjadinya kenakalan remaja. 
Fondasi penting untuk mencegah remaja dari aktivitas seksual pranikah adalah agama. Moral dan religi dapat mengendalikan tingkah laku remaja sehingga tidak melakukan hal-hal yang merugikan atau bertentangan dengan pandangan masyarakat. Pemahaman agama yang berkelanjutan pada remaja dapat membentuk pribadi yang berperilaku positif dan mencegah perilaku negatif, seperti perilaku yang berisiko.

Remaja melakukan hubungan seks pranikah disebabkan oleh berbagai faktor dan faktor yang berperan penting adalah situasi yang mendukung terjadinya seks pranikah tersebut. Remaja melakukan hubungan seks pranikah akibat situasi atau kesempatan remaja bersama-sama didalam ruangan yang pribadi dan kondisi ini disebut situations of sexual possibility. Selain itu alasan remaja melakukan hubungan seks pertama kali karena hasrat atau dorongan seksual.

Sebagian besar remaja tidak mengetahui dampak dari perilaku seksual yang mereka lakukan, seperti remaja hamil di luar nikah, aborsi, penyakit kelamin, dll. Karena kurangnya pengetahuan remaja tentang seksualitas, sehingga menimbulkan kenyataan-kenyataan pahit atau dengan kata lain, dari beberapa kenyataan pahit yang sering terjadi pada remaja sebagian akibat pemahaman yang keliru mengenai seksualitas.pendidikan seks perlu dilakukan untuk mencerahkan siswa remaja dalam masalah HIV / AIDS dan penyakit menular seksual lainnya dan tentang pentingnya tes HIV.

\section{PENUTUP}

1. Teruntuk remaja sebagai harapan masa depan bangsa, seharusnya remaja mengetahui benar tanggung jawab dan kewajiban besar yang dibebankan di bahu mereka. Oleh karena itu, agar tidak terjerumus ke hal-hal negatif yang merugikan diri sendiri maupun pihak lain, maka mahasiswa harus membentengi diri dengan cara memperdalam pengetahuan agama, yang bisa dilakukan dengan cara memperbanyak membaca buku keislaman, rajin mengikuti ceramah keagamaan, mengikuti kegiatan/organisasi keagamaan atau organisasi lain yang bermanfaat, bergaul dengan teman-teman yang baik. Dengan cara-cara tersebut dapat terhindar dari pengaruh buruk lingkungan yang akan menjerumuskan dalam perbuatan maksiat, yang merupakan pelanggaran terhadap agama maupun norma masyarakat.

2. Teruntuk orang tua, sikap orang tua yang kurang memperhatikan anak bahkan untuk hal kecil/sepele seperti cara berpakaian ternyata berpengaruh terhadap perilaku seks bebas. Oleh karena itu orang tua harus meluangkan waktu untuk memperhatikan anak, serta mengontrol kegiatan mereka. Orang tua juga harus menerapkan kedisiplinan beribadah/beragama dengan cara memberi teladan yang baik. Intinya, orang tua harus senantiasa mendampingi anak, terutama pada masa perkembangan dan masa transisi (peralihan) karena pada masa itulah, anak-anak mudah sekali terpengaruh lingkungan, agar terhindar dari perilaku-perilaku negatif yang dapat merugikan dirinya sendiri dan juga orangtua.

3. Teruntuk tokoh/pemuka agama, mengingat bahwa agama merupakan fondasi bagi kita untuk berperilaku, maka para tokoh agama seharusnya secara kontinyu mengadakan kajian keagamaan di tempat masing-masing, mengadakan kegiatan-kegiatan yang dapat meningkatkan keimanan dan ketakwaan pada Allah SWT, 


\section{Daftar Pustaka}

1. Ardina,M. (2017). Akses Informasi Kesehatan Reproduksi. Jurnal Komunikasi. Vol 9

2. Hamka,M. Hos,H.J.\& Tawulo,M.A. Perilaku Seks Bebas Dikalangan Remaja

3. Nadeak, B., dkk. (2020). Sexuality in Education Begins in The Home. Jurnal Comunita Servizio. Vol 2

4. Rahadi, S.D., Indarjo,S., (2017). Perilaku Seks Bebas Pada Anggota Club Motor X Kota Semarang Tahun 2017. Jurnal of Health Education. Vol 2

5. Rahmawati, I., dkk. (2018). Confirmatory Factoranalyses Of Adolescent Education Character By Families/Parents In Premarital Sexual Prevention In Jember Indonesia. Nurseline Journal. Vol 3

6. Rosyana,K.Kusnanto.\&Wahyuni,D.E. Analisis Faktor yang Berhubungan Dengan Prilaku Seks Bebas Pada Remaja di SMK Dr. Sutomo Surabaya berdasarkan Teori Prilaku WHO.

7. Sari, N.D., Darmana, A., (2018). Pengaruh Faktor Predisposisi, Pemungkin, Dan Pendorong,Terhadap Perilaku. Jurnal Kesehatan Global. Vol 1

8. Simamora, R. H. (2019). Menjadi perawat yang: CIH'HUY. Surakarta: Kekata Publisher.

9. Simamora, R. H. (2005). Hubungan Persepsi Perawat Pelaksana Terhadap Penerapan Fungsi Pengorganisasian Yang Dilakukan Oleh Kepala Ruangan Dengan Kinerjanya Diruang Rawat Inap RSUD Koja Jakarta Utara (Doctoral dissertation, Tesis FIK UI, Tidak dipublikasikan).

10. Sumiarsih,P.T. Marsiati,H. \& Endrini,S. (2019). Peningkatan Pengetahuan Faktor-faktor yang Mempengaruhi Perilaku Seks Dalam Upaya Cegah Seks Pranikah Pada Siswa/i SMPN 77 dan SMAN 77 Jakarta Pusat. Jurnal Pengabdian Kepada Masyarakat. Vol 4

11. Suhaida,S. Hos,J.H. \& Upe,A. (2018). Pergaulan Bebas Dikalangan Remaja. Neo Societal. Vol 3

12. Ungsianik,T. Yuliati,T. (2017). Pola Asuh Orangtua Berhubungan dengan Perilaku Seksual Beresiko Pada Remaja Binaan Rumah Singgah. Jurnal Keperawatan Indonesia. Vol 20 
